\title{
ESP TEACHING STRATEGIES BASED ON LANGUAGE LEARNERS' BELIEFS
}

\author{
L.Yu. Korolyova, E.Yu. Voyakina
}

\begin{abstract}
The paper deals with teaching Business English according to language learners' beliefs and attitudes. The study was conducted among first and second-year students doing Business English course in high school and having different levels of language fluency. The authors discuss the most efficient teaching strategies used in teaching Business English in interaction with students' needs and expectations, which helps teachers to improve learning outcomes. The research shows that the most productive teaching strategies are communicative, practice-oriented, and relevant to the subject matter.

Key words: Business English; communicative skills; language learners' beliefs; learning environment; teaching strategies.
\end{abstract}

\section{Introduction}

In the modern methodology of ELT, learners' beliefs and attitudes as well as learners' motivation and capacity are considered as key points in successful L2 learning and teaching. These beliefs refer to internal factors, and are defined as "general assumptions that students hold about themselves as learners, about factors influencing learning and about the nature of language learning" [1. P. 224].

In this Chapter we will analyze students' beliefs and expectations at different stages of studying English at Tambov State Technical University and focus on efficient teaching strategies which are used in accordance with these attitudes.

\section{The present study}

At Tambov State Technical University (TSTU) the English course lasts four years and is divided into two stages. The first stage is teaching English to first- and second-year students; the second stage - to third- and fourth-year students. According to the curriculum, English is studied at the university as a second language for two academic hours a week. During the first two years, students are taught General English, while third- and fourthyear students learn English for Specific Purposes (ESP).

There are two objectives of the study: 1) to compare students' beliefs at the preliminary stage before beginning to learn English at the university and at the end of the first stage before being taught ESP; 2) to analyze teaching strategies used at both stages. 


\section{Participants}

The study is based on the Language Learning Beliefs Questionnaire (see Appendix 1).

100 first-year students and 100 second-year students of Tambov State Technical University were asked to respond to the statements given in the questionnaire. The answers could vary from "strongly agree", through "agree" and "neutral" to "disagree" and "strongly disagree".

\section{The results of the study (stage I)}

In general the students evaluated 20 statements concerning their language learning beliefs. All the results of this questionnaire are given in the following table 1 .

Ta ble 1

\section{Language learning beliefs questionnaire results}

\begin{tabular}{|l|c|c|c|c|c|}
\hline \multicolumn{1}{|c|}{ Questions } & $\begin{array}{c}\text { Strongly } \\
\text { agree } \\
\text { (st-s) }\end{array}$ & $\begin{array}{c}\text { Agree } \\
\text { (st-s) }\end{array}$ & $\begin{array}{c}\text { Neutral } \\
\text { (st-s) }\end{array}$ & $\begin{array}{c}\text { Disagr } \\
\text { ee } \\
\text { (st-s) }\end{array}$ & $\begin{array}{c}\text { Strongly } \\
\text { disagree } \\
\text { (st-s) }\end{array}$ \\
\hline $\begin{array}{l}\text { 1. People over 40 will probably find it hard } \\
\text { to learn a foreign language }\end{array}$ & 10 & 50 & 0 & 30 & 10 \\
\hline $\begin{array}{l}\text { 2. If you don't have a special aptitude it } \\
\text { will be really hard to learn one well }\end{array}$ & 0 & 50 & 40 & 10 & 0 \\
\hline $\begin{array}{l}\text { 3. It's really important to have your errors } \\
\text { corrected from the start when you are } \\
\text { learning a language or you will never speak } \\
\text { correctly }\end{array}$ & 80 & 10 & 0 & 0 & 10 \\
\hline $\begin{array}{l}\text { 4. Grammar drills are very important in } \\
\text { mastering a foreign language }\end{array}$ & 60 & 40 & 0 & 0 & 0 \\
\hline $\begin{array}{l}\text { 5. You can learn a foreign language more } \\
\text { easily if you like the people who speak that } \\
\text { language }\end{array}$ & 30 & 60 & 10 & 0 & 0 \\
\hline $\begin{array}{l}\text { 6. The best way to learn another language } \\
\text { is to forget about lesson plans or grammar, } \\
\text { but just spent time with people who speak } \\
\text { the language }\end{array}$ & 0 & 30 & 30 & 30 & 10 \\
\hline $\begin{array}{l}\text { 7. You shouldn't say anything in a new } \\
\text { language until you can say it correctly }\end{array}$ & 0 & 0 & 20 & 40 & 40 \\
\hline $\begin{array}{l}\text { 8. Some languages are by their nature } \\
\text { harder than others }\end{array}$ & 10 & 50 & 20 & 20 & 0 \\
\hline $\begin{array}{l}\text { 9. Attitude contributes as much as } \\
\text { intelligence to language learning success }\end{array}$ & 20 & 40 & 40 & 0 & 0 \\
\hline $\begin{array}{l}\text { 10. If you can analyze how a language } \\
\text { works, you'll be able to speak it well }\end{array}$ & 40 & 50 & 10 & 0 & 0 \\
\hline $\begin{array}{l}\text { 11. You are learning a language if you } \\
\text { can understand it, even if you can't } \\
\text { speak it }\end{array}$ & 20 & 20 & 30 & 20 & 10 \\
\hline
\end{tabular}




\begin{tabular}{|l|c|c|c|c|c|}
\hline \multicolumn{1}{|c|}{ Questions } & $\begin{array}{c}\text { Strongly } \\
\text { agree } \\
\text { (st-s) }\end{array}$ & $\begin{array}{c}\text { Agree } \\
\text { (st-s) }\end{array}$ & $\begin{array}{c}\text { Neutral } \\
\text { (st-s) }\end{array}$ & $\begin{array}{c}\text { Disagr } \\
\text { ee } \\
\text { (st-s) }\end{array}$ & $\begin{array}{c}\text { Strongly } \\
\text { disagree } \\
\text { (st-s) }\end{array}$ \\
\hline $\begin{array}{l}\text { 12. It is easier for someone who already } \\
\text { speaks a foreign language to learn another } \\
\text { one }\end{array}$ & 30 & 60 & 10 & 0 & 0 \\
\hline $\begin{array}{l}\text { 13. It is easier to speak than to understand a } \\
\text { foreign language }\end{array}$ & 10 & 20 & 30 & 20 & 20 \\
\hline $\begin{array}{l}\text { 14. Is it important to listen a lot before } \\
\text { starting to speak }\end{array}$ & 50 & 30 & 10 & 10 & 0 \\
\hline $\begin{array}{l}\text { 15. Learning a foreign language is different } \\
\text { from other academic subjects }\end{array}$ & 20 & 60 & 20 & 0 & 0 \\
\hline $\begin{array}{l}\text { 16. It is important to repeat and practice a } \\
\text { lot }\end{array}$ & 90 & 10 & 0 & 0 & 0 \\
\hline $\begin{array}{l}\text { 17. It is important to understand what parts } \\
\text { of a sentence mean when you are learning } \\
\text { to say it }\end{array}$ & 70 & 30 & 0 & 0 & 0 \\
\hline $\begin{array}{l}\text { 18. At some point you need to spend a year } \\
\text { or so in a country where the language is } \\
\text { spoken in order to become really fluent }\end{array}$ & 0 & 90 & 10 & 0 & 0 \\
\hline $\begin{array}{l}\text { 19. Memorizing dialogues is a good way to } \\
\text { learn a language }\end{array}$ & 30 & 50 & 20 & 0 & 0 \\
\hline $\begin{array}{l}\text { 20. Being anxious is usually harmful when } \\
\text { learning a foreign language }\end{array}$ & 10 & 20 & 70 & 0 & 0 \\
\hline The total number of answers & 580 & 790 & 370 & 180 & 100 \\
\hline
\end{tabular}

\section{The questionnaire analysis and teaching strategies} (Stage I)

The language-learning belief (1): Most of the students (60\%) agree that it is hard for people over 40 to learn a foreign language. $40 \%$ of the students disagree with this statement. It means that many 17- and 18-year-old people take into consideration those limits that a person's age can set, thus taking an advantage of their youth for learning a foreign language. Other respondents do not pay attention to age limits and think that everything depends on an individual and that it is never too late to learn.

The teaching strategy: Relying on the first part of the students $(60 \%)$, a foreign language teacher can encourage them to take full advantage of their age and try to master the studied language.

The language-learning belief (2): The second statement concerns a special aptitude without which it will be hard to learn a foreign language quite well. It seems to be a rather dubious statement as 40 respondents are neutral, while 50 of them agree with it.

The teaching strategy: The results imply the idea that a foreign language teacher should help students develop different skills in all types of communicative activity so that students will not feel deprived of the aptitude to learn a foreign language even if they have some difficulties. Thus, at our 
lessons of English we use an individual approach to students giving more difficult tasks to those for whom it is quite easy to learn a foreign language, and simpler tasks to those who find it complicated.

For example, the English language course for the first-year students includes the following topics: Personality, Travel, Work, Language, Advertising, Business [2]. Language groups consist of approximately 10 students and in case most of them have problems while learning English, teachers either simplify all the tasks or exclude those ones which are very difficult for the students. For instance, while doing Lesson 4 "Scenario" of Unit 1 "Personality", the teacher asks the students to describe themselves (interests, hobbies) instead of analyzing those candidates whose profiles are given in the coursebook. If the students in the group have different abilities, more advanced students should discuss these candidates, choose the best one according to the requirements given in the coursebook and explain their choice. Other students are given the task to ask each other questions about their qualities, interests, traits of character and so on. This helps all the students understand that they have abilities for learning a foreign language.

The language-learning belief (3): The third statement gives an idea about the importance of error correction from the start. It is surprising that $80 \%$ of the students strongly agree with this, as people do not usually like when they are corrected all the time. It is assumed that correcting every mistake can discourage students and prevent them from learning a foreign language at all. However, the results of the questionnaire show that the students want to be corrected in order to speak a foreign language properly.

The teaching strategy: At our University we usually apply the following method based on an individual approach: if a more advanced student makes mistakes we try to correct most of them, a less confident student's errors are corrected partially, only the most important ones.

The language-learning belief (4): $100 \%$ of the students agree with the statement that grammar drills are important in mastering a foreign language. This indicates that our students have a very serious attitude to learning a foreign language and understand that it is impossible to master it without grammar.

The teaching strategy: At our lessons after the explanation of some grammar aspect teachers make the students use it in practice in different types of communicative activity. For example, while studying Unit 3 "Work" the teacher draws the students' attention to the use of Present Perfect Continuous. Firstly, grammar exercises from the coursebook are done. Then, the students should give their own examples and ask each other questions using Present Perfect Continuous. After that, more additional grammar exercises are given. At the next lesson, the teacher tells the difference between Present Perfect and Present Perfect Continuous. After taking some 
grammar exercises, the students do a job interview, ask and answer questions using these tense forms.

The language-learning belief (5): $90 \%$ of the students agree that it is possible to learn a foreign language more easily if you like the people who speak that language.

The teaching strategy: At Tambov State Technical University, teachers of English often invite English-speaking students to their lessons to give the learners an opportunity to speak and learn the language through communication with native speakers.

The language-learning belief (6): We can single out three groups according to the response to the statement about learning a foreign language without any lesson plans or grammar, but simply by spending time with those who speak that language. There are $30 \%$ of those who agree, $30 \%$ of those who disagree and $30 \%$ who are neutral. The results are a bit contradictory as in the fourth statement most of the students agree with the necessity of grammar drills. This means that the first-year students are not sure which way is the best.

The teaching strategy: It is the teacher's responsibility to show students that the most efficient method of learning a foreign language is to combine several ways. Consequently, it is important to learn grammar as well as to communicate with native speakers.

The language-learning belief (7): Most of the respondents (80\%) disagree with the opinion that you should not say anything in a new language until you can say it correctly. We admit that this is the right approach to learning a foreign language because it is necessary to practise first and even mispronounce something, but this is just the right way to learn something new. It is impossible to say something new correctly at once.

The teaching strategy: At our lessons, while teaching new vocabulary we make the students repeat the words several times in chorus and sometimes individually, and then use them in speech.

The language-learning belief (8): 50 students agree that some languages are more difficult by their nature than others, and only $20 \%$ of the respondents disagree with this.

The teaching strategy: It is necessary to give students examples of other foreign languages and explain the sentence structure and word formation to them. They will be able to find out similarities and differences in such a way, and understand that some languages are quite difficult, for example, Chinese, Japanese etc, and in comparison with them English is simple. It is possible to master it in a full way to feel yourself a world citizen.

The language-learning belief (9): The response to the statement about the equal contribution of attitude and intelligence to language learning success divided the students into groups: those who agree (40\%), those who are neutral $(40 \%)$ and those who strongly agree $(20 \%)$. This also indicates that it 
is rather difficult for the first-year students to identify the factors which are important to achieve a success in language learning.

The teaching strategy: The teacher's task is to develop the right attitude as well as students' intellectual abilities by giving the exercises which are aimed at this. For example, while studying the topic "Travel", the teacher can ask the students to remember famous explorers and scientists and their contribution to the world history or science. It can be a quiz, a crossword, "a round table". While studying the topic "Business", facts about famous businessmen and their achievements can be given, and the students should try to remember these businessmen.

The language-learning belief (10): Practically all the respondents $(90 \%)$ agree that if you can analyze how language works, you will be able to speak it well.

The teaching strategy: It is quite important to explain the language structures and their use, word formation, grammar rules to the students, teach them to form these structures and use them appropriately. One of the exercises based on this principle is the formation of necessary parts of speech of the given nouns, adjectives or adverbs according to the context (e.g. to observe-observer-observation).

The language-learning belief (11): The opinions about the next statement "You are learning a language if you can understand it even if you cannot speak it" are different: some of the students agree with it (40\%), some of them disagree $(20 \%)$, others are neutral $(30 \%)$.

The teaching strategy: The results show that the first-year students want to both understand a foreign language and speak it. It is true that if you know a language you have necessary skills in all four types of communication: speaking, writing, listening, and reading. But in many cases understanding is the first step to successful language learning. It is the basis for the development of all other skills. So, the teacher should pay attention to this.

The language-learning belief (12): Most of the students (90\%) express their agreement with the idea that it is easier for someone who already speaks a foreign language to learn another one.

The teaching strategy: Though the students responded to this statement in such a way, it shows only their point of view but not experience, as in Russia not many people know two or three foreign languages. The opinion is supported by the fact that if a person has an aptitude for learning foreign languages, he or she can achieve a success in all of them, but it is true that everything depends on an individual. Some people are really able to learn many foreign languages, but others cannot cope even with one. This is stipulated by a lot of factors. In practice in universities where students have an opportunity to learn two foreign languages, many of them have difficulties with the second language, because two languages interfere with each other. 
For example, it often happens with English and German. Therefore, it is not so easy to learn the second foreign language if you already know one.

The language-learning belief (13): The statement that it is easier to speak than to understand a foreign language divided the respondents into three groups: those who agree (30\%), those who disagree $(40 \%)$ and those who are neutral (30\%).

The teaching strategy: It justifies the idea about the necessity to be able to speak as well as to understand a foreign language no matter what can be easier. The teacher should develop both skills in students. At our University, for example, before doing exercises from the "Listening" section, we give the students pre-listening tasks, asking questions that can help understand the speakers better. The students express their viewpoints speaking English.

The language-learning belief (14): The statement concerns the importance of listening a lot before starting to speak. $80 \%$ of the students agree with this.

The teaching strategy: At our lessons we usually combine listening and speaking and do not separate them. For instance, while studying the topic "Language", Lesson 4 "Scenario: Language training" the students are asked to express their opinion about language training courses after reading some information about them. Then they listen to three representatives of the HR department of the independent charity organization about different forms of language training courses, which they can organize in their company, their advantages and disadvantages. Students make notes while listening to them. After that they should summarize the opinions of three representatives and express their points of view on these language training courses.

The language-learning belief (15): 80\% of the respondents agree that learning a foreign language is different from learning other academic subjects.

The teaching strategy: The results are quite logical as foreign languages is such a different sphere of the human knowledge that it cannot be compared with anything else. It has its own peculiarities and deals with the communication of people, first of all. Therefore, at our lessons we constantly draw the students' attention to the fact that this foreign language is necessary for the communication with people from other countries.

The language-learning belief (16): All the respondents (100\%) admit that it is important to repeat and practise a lot.

The teaching strategy: It is good that the first-year students understand this and it is easy to encourage them to do different exercises aimed at mastering a foreign language. That is why studying any topic teachers ask students to read a lot, to speak a lot, to listen a lot and to write whenever necessary. Apart from doing compulsory exercises in the coursebook, students get additional tasks dealing with situations from the real life. For example, when 
we study the topic "Work", we ask the students to find job advertisements in newspapers, write their CVs according to the requirements set in these advertisements, analyze these CVs, point out good and bad features, recommend using additional information if necessary, and then role-play job interviews.

The language-learning belief (17): All the students (100\%) think that it is important to understand "what the parts of a sentence mean when you are learning to say it".

The teaching strategy: It contradicts the idea about teaching somebody a foreign language when you explain the meaning of the whole sentence, but not of the sentence parts. This can be useful for children. The questionnaire shows that 17-and-18-year-old people would like to understand what they learn in detail. That is why we usually explain the general sentence structure in the English language to our students. Then they learn topical vocabulary and teachers encourage them to make sentences using the known words and the rules about the sentence structure. We also give them exercises where it is necessary to correct the word order or change the parts of sentences according to the context.

The language-learning belief (18): $90 \%$ of the respondents think that at some point you need to spend a year or so in a country where the language is spoken in order to become really fluent.

The teaching strategy: It is quite true, that the atmosphere of a foreign country makes people who come there speak the language of this country. They have to do it, because otherwise they will not be able to live in this country and satisfy their everyday needs. At our lessons we try to create some part of this atmosphere, at least. Here we rely on video clips, use the authentic material from the Internet.

The language-learning belief (19): Practically all the respondents $(80 \%)$ agree that memorizing dialogues is a good way to learn a language.

The teaching strategy: It can be surprising on the part of the first-year students because such tasks are usually given to children. On the whole, it is useful to learn dialogues by heart with framing expressions and frequently used words. At the same time it is a good exercise for a person's memory. However, at TSTU we encourage the students to make up dialogues themselves as they need to practise such situations which are close to real ones, when they have to express their own ideas and points of view. As for framing expressions it is possible to learn them by heart separately.

The language-learning belief (20): 70 respondents are neutral about the last statement which expresses the idea that being anxious is usually harmful when learning a foreign language.

The teaching strategy: The first-year students are certainly not sure about their anxiety and its influence on their learning abilities. This statement is related to psychology and those problems which it solves. We can suppose that the state of anxiety is not good for a person though it depends 
on an individual. In some cases, anxiety helps a person get hold of himself or herself and control the situation better, but in most cases it is rather harmful as a person begins to feel nervous, it influences his or her speech, he or she can even stammer and have other problems. However, it concerns any language, not only a foreign one, but a native language as well. On the whole, at our lessons we try to create such an atmosphere that can let the students feel comfortable. They should not be afraid of expressing their points of view in English or making mistakes.

So, these are the language learning beliefs that TSTU students have at the preliminary stage, and the teaching strategies which are used according to them.

\section{The level of language learners' beliefs}

In addition, the students were asked to score their answers. This gave us an opportunity to analyze the level of their language learning beliefs. The results are shown in table 2 (10 students' answers are presented in it).

Table 2

Students' language learning beliefs

\begin{tabular}{|c|c|c|c|c|c|}
\hline Students & Strongly agree & Agree & Neutral & Disagree & $\begin{array}{l}\text { Strongly } \\
\text { disagree }\end{array}$ \\
\hline 1 & $\begin{array}{c}40-\text { above } \\
\text { average }\end{array}$ & 48 - high & 16 - average & $2-$ low & $0-$ low \\
\hline 2 & $80-$ high & 24 - average & 16 - average & $4-$ low & $0-$ low \\
\hline 3 & 48 - high & $72-$ high & $4-$ low & $0-$ low & $0-$ low \\
\hline 4 & $\begin{array}{l}40 \text { - above } \\
\text { average }\end{array}$ & $54-$ high & 20 - average & $0-$ low & $0-$ low \\
\hline 5 & 16 - average & 54 - high & 20 - average & $6-$ low & $0-$ low \\
\hline 6 & 56 - high & $\begin{array}{c}36-\text { above } \\
\text { average }\end{array}$ & $8-$ low & $6-$ low & $0-$ low \\
\hline 7 & $\begin{array}{c}40-\text { above } \\
\text { average }\end{array}$ & $60-$ high & 16 - average & $2-$ low & $0-$ low \\
\hline 8 & $\begin{array}{c}40-\text { above } \\
\text { average }\end{array}$ & $\begin{array}{c}36-\text { above } \\
\text { average }\end{array}$ & 20 - average & $4-$ low & $0-$ low \\
\hline 9 & 48 - high & $\begin{array}{c}36-\text { above } \\
\text { average }\end{array}$ & $8-$ low & $10-$ low & $0-$ low \\
\hline 10 & 56 - high & $\begin{array}{c}42-\text { above } \\
\text { average }\end{array}$ & 16 - average & $2-$ low & $0-$ low \\
\hline
\end{tabular}

We can say that most of the first-year students strongly agree or agree with the statements, and therefore, they have high beliefs and beliefs above average about learning a foreign language. This can also be seen in the diagram (fig. 1). 


\section{Language learners' beliefs (stage I)}

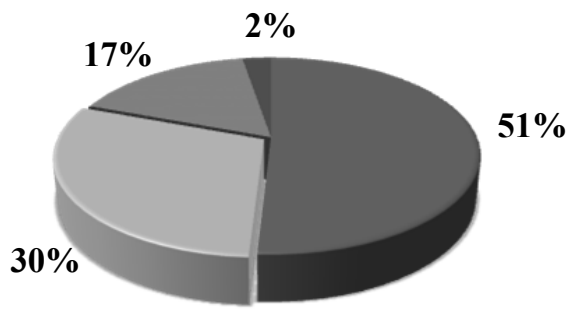

$\square$ High

$\square$ Above

average

Fig. 1. Language learners' beliefs at the first stage

Thus, it is clear that the interviewed students have a good intention and are quite ready for learning foreign languages at the preliminary stage.

\section{The results of the study (stage II)}

At the second stage, our research involved students of Economics at the beginning of studying Business English (100 students). The ESP course has been introduced into the curriculum of third and fourth-year students as it is necessary for them to study ESP in connection with their majors. In this case students have a particular purpose and the focus is on learning the language as they study English not only to understand everyday speech, but also use the language in a special context for career opportunities. The ESP program is, therefore, built on the assessment of purposes and needs, and the functions for which English is required.

The responses of those students to the questionnaire statements are a bit different from the above mentioned. The results within that group of students are shown in the following diagram (fig. 2).

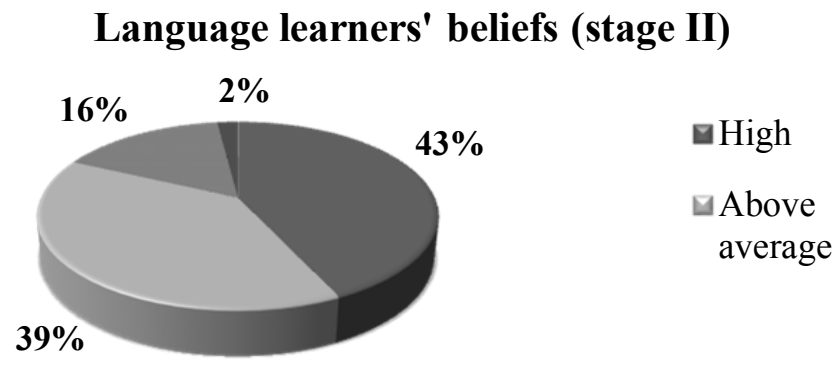

Fig. 2. Language learners' beliefs before the ESP stage 


\section{The comparative analysis of language learners' beliefs at two stages}

According to the diagrams, the first-year students have a larger percentage of high beliefs ( $51 \%$ vs $43 \%$ ) than the second-year students while the latter have a higher percentage of beliefs above average (30\% vs 39\%). As for those who have average beliefs as well as low beliefs, their percentage is practically the same (approximately $16 \%$ and $2 \%$, correspondingly). This can be explained by the fact that during the process of studying a foreign language students become more realistic and they estimate their abilities properly neither overvaluing nor undervaluing them. The ESP students are going to start their career and improve professional skills, and they already have some knowledge of General English. Consequently, they are learning the language in order to communicate in the professional area and do a particular job. So, most of the students for the reason of their sufficient General English level and future career opportunities have very high motivation and corresponding beliefs about their language learning.

\section{Teaching strategies (stage II)}

The students' beliefs about language learning at this stage are also closely linked to the choice of teaching strategies. This year we have published a new coursebook on Business English "Business Startup" and have taken it as a pilot project with our students. It comprises four units which relate to different spheres of business. Each unit includes four sections:

1. Life at work: Personal information, Jobs, Business facilities, Contacts.

2. Company: Who do you work for?, Activities, Introducing your business, Successful companies.

3. Making a career: Job hunting, Job interview, Teambuilding, Leadership.

4. Travel: Travel arrangements, At the airport, Hotel reservation, Cross-cultural aspects and dining etiquette.

The coursebook is aimed at training oral and written communication and developing intercultural skills, including stereotypes of thinking and behaviour in the English culture. The emphasis of this coursebook is made on practising communicative skills in the frame of business. At the end of the course students are supposed to use English as a means of business communication, know general and special business vocabulary as well as basic business terminology, be able to do business correspondence, i.e. students should work and communicate independently at the international level.

On the one hand, the difference of teaching ESP (in our case it is Business English) during the third and fourth years from teaching General English during the first and second years consists in the choice of contexts 
for listening and reading texts and in the choice of lexis in grammar and vocabulary exercises, where examples such as "I'm going on business trip" replace "I'm going on holiday".

On the other hand, teaching Business English requires the teacher's awareness of the subject matter. As a matter of fact, ESP combines the subject matter and English language teaching skills. The role of the teacher at this stage is to adapt teaching skills and strategies for teaching Business English. Such integration is very motivating for students because they will have an opportunity to put into practice their knowledge acquired during their Business English lessons in their majors, whether it is Economics, Commerce, Business Management or Marketing.

Moreover, not to lose students' interest (and that is one of the most difficult points of teaching) and strengthen their language learning beliefs the teacher should prepare for the lesson more thoroughly. For example, the teacher should know key business terminology, company structure, as well as the basics of business correspondence and telephoning, negotiating, job interviewing, etc. Practising the vocabulary and structures that students learn in a specific meaningful context consolidates what is taught and increases their motivation.

One of the helpful and useful ESP teaching strategies used at our lessons is explaining terms or business realities. Third and fourth-year Economics students are supposed to have enough knowledge of the key economic and business matters. So, we can ask them to explain these terms in English, e.g. what is a balance sheet and how does it work? or what is back pay? While students speak, the teacher can help them giving additional words and phrases, correcting their mistakes. This kind of the task is very productive with our students as they do not only show their subject knowledge but also use topical vocabulary. Besides, students' answers provide the teacher with the information about students' grammar or word order weaknesses, gaps in their vocabulary or pronunciation problems. Thus, such tasks help the teacher give students some practice both in their subject matter and the language.

To increase learners' motivation we often use as a strategy of teaching business idioms (also included into our course book). For learners the comprehension of idioms is facilitated by contextual support. The students enjoy the challenge to interpret idioms according to the context and find their Russian equivalents. Other tasks include matching business idioms with their corresponding definitions, substituting for the underlined phrase an idiom with the same meaning, solving quizzes, making dialogues using idioms, etc. In order not to overload learners with idiomatic expressions and involve them in communication without losing their interest, we suggest such teaching strategies as choosing idioms that are frequently used in the target language. They are not very complicated with grammar and vocabulary and have comprehensible figurative meanings (e.g. parent company, a start-up, a 
sleeping partner, rat race, cash cow, a skeleton staff, to shop around, to throw good money after bad, etc.). More complex idioms, like seagull manager, white / black knight, brownie points, etc., should be clearly explained, illustrated with examples and then practised within the larger context of a short paragraph or a dialogue.

For example, one of the efficient tasks is sketching a situation that elicits learners' answers with the help of idioms, e.g. asking for a loan, discussing how to increase sales or solving problems of going bankrupt. To help students the teacher can divide idioms into several categories that will be useful in each situation. It is very important to give students instructions and help them succeed in learning idioms.

As many learners have high beliefs about the importance of vocabulary in language learning, the teacher uses strategies that support vocabulary learning such as memorizing words, making a list of new words and practising them in different exercises.

Concerning students' beliefs about grammar learning, we can say that it is not of such an importance in mastering Business English. Most students doing the ESP course are not interested in grammar corrections if they are sure that other people can understand them. It is more important for them to have a lot of speaking practice though they admit that if you can analyze how a language works, you will be able to speak it well. In the process of teaching ESP grammar takes a second place. Still, it should be taught. To meet students' needs the teacher has to make task-based grammar exercises, i.e. use authentic articles for discussing business issues, or writing official business letters that contain correct grammar structures.

Another thing in teaching business grammar is using such grammar material that can be appropriate for specific business situations. For example, making future business arrangements can involve using the Present Continuous tense, passing on information supposes using reported speech, whereas comparing business offers deals with comparative and superlative forms of adjectives. In some cases grammar structures can be drilled while practising for developing such skills as telephoning, emailing or negotiating. The teacher can use it as the basis of grammar presentation, e.g. by giving students sentences they have seen before like "I look forward to hearing from you" with the prepositions blanked out. It can also be used for the review of tenses, determiners, modal verbs. Thus, grammar, of course, must be taught, but in the subject matter context. Such activities have a necessary learning objective, but students appreciate them.

At the lessons of Business English the teacher should always remember to practise not only business vocabulary and grammar but also communicative skills. In order to develop learners' communicative skills we often use teaching strategies which involve the following tasks: 
- Making presentations.

Our students usually enjoy such tasks, because they imply creativity and freedom. Asking learners to make a presentation about a particular product, company or their current research is always a highly focused activity, where the teacher can both give directions at the preparation stage (useful vocabulary and grammar, steps of presenting material) and feedback on the performance (discussing language mistakes, presentation construction). The teacher can get benefit from this strategy viewing it as both a teaching and learning process, where some interesting information about different business processes can be acquired.

One of the examples of such tasks is when the students are asked to prepare a presentation of a company and describe its main activities and specialization, staff, main markets, organization, etc. Useful phrases are divided into several parts: opening part - introduction (I'm..; I'm going to talk about..; I'd like to give you some background information.., etc.), organizing the presentation - describing a company and its structure (founded in.., divided into.., consists of.., includes, employs, cooperates with.., etc.) and closing part - summarizing (To sum it up.., If you have any questions.., etc.). The teacher can enrich these parts with more phrases and ask students to use grammar structures viewed in the topic (connectors, Passive voice, modals, etc.). Visual aids are always welcome as students also practise how to work with slides. After the presentations all students discuss their weak and strong points and make recommendations for improvement.

- Making a telephone call.

This strategy is often implemented in the form of a dialogue. Training telephone English in class can sometimes seem rather artificial as learners are usually asked to practise speaking on the phone through role-plays in pairs or small groups. To diversify and enliven lessons of English the teacher can focus on creating more realistic situations to encourage students to practise authentic telephone conversation.

Before the task we usually review phrases used in telephoning. The teacher gives helpful opening and closing phrases for greeting, introducing (This is ... speaking), starting a conversation (Could I speak to..?, I'd like to talk to...), asking for something (Could I leave a message?, Can he call me back as soon as possible?, Can I have his contact number?), answering the phone call (The line is busy at the moment, Hold on, please), making appointments (Let's.., We are meeting at.., Shall we meet..?), repeating (So that's.., Is that right?), ending a call (I'll call back later, Glad to hear from you). Then students are asked to role-play different situations like "You call to your partner's office but he is not here. Leave a message" or "You need to organize a meeting with an advertizing manager. Make an arrangement".

- Holding negotiations. 
This strategy can be implemented as a group work in the form of a round table with the chair of the meeting and people who take part in it. Before the meeting itself the teacher should discuss with the students the key points in making negotiations successful (how people should behave and react, what they should get in the result).

The topics for negotiations may be given at the previous lesson for the students to be ready to give some ideas on the issues. The topics can include negotiations within the company about launching a product or with a company's partner about cooperation, or it may be a talk of an employee with the boss about the salary, promotion, holidays, etc.

The useful vocabulary is very important to students as they need to know how to disagree, share opinions, be both insistent and polite, clarify goals and so on. The vocabulary can be grouped into parts:

- opening (naming topics for discussion): I'd like to discuss.., The question needs to be discussed;

- participating (negotiating, expressing opinions, making suggestions, interrupting, arguing, agreeing / disagreeing): I (can't) agree with you, In other words, you feel that.., I don't see any problem with / harm in that, I understand where you're coming from, however.., I'm prepared to compromise but.., To my mind.., In my opinion.., The way I look at it.., I'm afraid I had something different in mind, Is that your best offer?;

- closing a meeting (summarizing): It sounds like we've found some common ground, Let's leave it this way for now, I think we both agree to these terms, Shall we meet again to discuss it?

The teacher should not avoid reviewing the grammar material necessary for doing this task (modal verbs, conditionals, connectors, etc.). During the negotiations the teacher constantly monitors the process and helps students with time limits and vocabulary.

After the task is done, students always give their feedback and tips for improving both the language and atmosphere of the meeting.

- Writing a business letter / CV / covering letter.

To use this strategy the teacher should explain the structure of the letter to the students and analyze a sample of a business letter / CV / covering letter. If the task is to write a business letter, students are given a tip sheet, which helps them write the body paragraphs of a letter. The teacher should explain the importance of avoiding contractions, ambiguity and passive voice and that a business letter should be as prompt as possible and focus only on the most relevant points.

To write a CV for a given job, we encourage students to use a computer for creating and sending their CVs and covering letters by e-mail. Then we ask students to exchange their CVs and check them, arrange job interviews, where one group of students plays the role of candidates and the others act as interviewers. Thus, the task helps to practise writing and speaking skills. 
All mentioned strategies are valuable, because they develop both students' language and communicative skills integrating with each other. Besides, students learn to use their knowledge acquired at the lessons of Economics, Management, etc. in practice. But we must admit that if the teacher has a group where the students show different levels of language proficiency, tasks and roles should be distributed in such a way that the students will be able to cope with them and even catch up with more advanced students.

Apart from using the above motioned teaching strategies, there is one more important factor in teaching ESP - that is creating a positive learning environment in the classroom when evaluating learners' progress. The interviewed students mostly disagree that people should not say anything in a new language until they can say it correctly. It shows that practice is very important for students even if they do not have enough language proficiency. Most of the students note that their beliefs are often defined by the context in which they learn as well as their previous learning experience. To make it more comfortable for the students, the teacher can use different games for practising all sorts of business vocabulary, grammar and developing their communicative skills.

Incorporating authentic video materials in Business English is also an efficient teaching strategy that consolidates learners' beliefs and presents a challenge to the learners bringing about a sense of 'realness' to the learning process. Working with authentic materials (e.g. videos, newspaper and journal articles on economics, business issues, etc.), can be interesting and useful for students' future professional activity. However, the teacher should always remember about the level of learners and therefore try to adapt video materials to this level, e.g. less advanced learners can be provided with transcripts. The difficulty of a given piece of material must be carefully assessed before the students watch it. There must be a lead-in stage introducing the material and giving some background information which can be based on newspaper articles, pictures, vocabulary exercises, etc. Comprehensive preteaching is necessary because even students with good command of General English may feel embarrassed with specialized information, terminology, idioms. The tasks may also be graded from easier to more challenging, depending on the level of learners.

Authenticity of materials serves as a tool for raising students' cultural awareness, thus contributing to the development of their communicative competences. Using authentic video materials enhances students' motivation as they feel that they are learning in a natural environment which meets their needs and beliefs. Besides learning the language, students can be taught some extra-linguistic features such as gestures, the body language, etc.

\section{Conclusion}

The survey shows that the students have high beliefs and beliefs above average concerning their language learning at the preliminary stage and be- 
liefs above average before the ESP stage. We can assume that the students wish to learn a foreign language. Their motivation and dedication are the highest points in the language learning process, following which the teacher should use the most efficient teaching strategies to get the best results. Teaching strategies, on the one hand, depend on language learners' beliefs which do not always cover all aspects of the language. On the other hand, it is compulsory for the teacher to develop students' skills in all types of communicative activity to make them master a foreign language. This also includes creating a friendly environment to help learners avoid stress, fear of failure that interfere with the learning process and can prevent students from learning the language successfully.

\title{
References
}

1. Victori Mia, Lockhart Walter. Enhancing metacognition in self-directed language learning. System. 23. 1995. P. 223-234.

2. Cotton David, Falvey David, Kent Simon Kent. Language Leader Intermediate. Pearson Education Limited, 2008.

СТРАТЕГИИ ПРЕПОДАВАНИЯ АНГЛИЙСКОГО ЯЗЫКА ДЛЯ СПЕЦИАЛЬНЫХ ЦЕЛЕЙ НА ОСНОВЕ ЯЗЫКОВЫХ УБЕЖДЕНИЙ УЧАЩИХСЯ

Королева Л.Ю. Тамбовский государственный технический университет (Тамбов, Россия). E-mail: lenakusa2005@mail.ru

Воякина Е.Ю. Тамбовский государственный технический университет (Тамбов, Россия). E-mail: lenakusa2005@mail.ru

\begin{abstract}
Аннотация. В статье рассматривается методика преподавания делового английского в соответствии с языковыми убеждениями учащихся. Было проведено исследование среди студентов первого и второго курсов, изучающих деловой английский в вузе и имеющих различный уровень языковой подготовки. Авторы обсуждают наиболее эффективные стратегии преподавания, используемые для обучения деловому английскому, во взаимосвязи с запросами и ожиданиями студентов, что позволяет преподавателям улучшить результаты обучения. Исследование показывает, что к наиболее продуктивным стратегиям преподавания относятся стратегии коммуникативного, практикоориентированного и тематически релевантного типа.
\end{abstract}

Ключевые слова: деловой английский; коммуникативные навыки; языковые убеждения учащихся; среда обучения; стратегии преподавания.

DOI 10.17223/19996195/30/17 